Vol. 5, No. 1, 2019

УДК 323.15

https://doi.org/10.23939/shv2019.01.043

\title{
PRIORITIES OF UKRAINIAN NATIONAL MINORITY ACTIVITIES IN WARMIAN-MASURIAN VOIVODESHIP OF REPUBLIC OF POLAND
}

\author{
Lesia Dorosh \\ Lviv Polytechnic National University \\ lesia.o.dorosh@lpnu.ua \\ Researcher ID R-1453-2017 \\ Author ID: 57192267003 \\ Yaryna Turchyn \\ Lviv Polytechnic National University \\ turchynj@ukr.net \\ Researcher ID R-1932-2017 \\ Author ID: 57192268948 \\ Teresa Astramowich-Leyk \\ University of Warmia and Mazury in Olsztyn \\ teresa.astramowicz@uwm.edu.pl \\ ORCID 0000-0001-5881-2325
}

(стаття надійшла до редколегї-17.03.2019 р., стаття прийнята до друку - 21.04.2019 р.)

The features, challenges and priorities of the Ukrainian community in the Warmian-Masurian Voivodeship have been analyzed. Also, it has been investigated the activities of the Ukrainian national minority in this region from the post-war times to the present day. It is alleged about the demand for studying of the problems of the functioning of the Ukrainian national minority in Poland in the regional dimension when it is analyzing the activities of Ukrainian communities located in the certain of the Voivodeships (in this case it is about the WarmianMasurian). This research is relevant in terms of identifying the factors that determine the development of comprehensive cooperation between Ukraine and Poland. The activity of three regional branches of the Union of Ukrainians in Poland has been analyzed. The efforts of local authorities in support of cultural projects of the Ukrainian national minority, in providing the financial and organizational support of their activities have been taken into account. The regularity has been confirmed - where there are enough of Ukrainians and they are sufficiently organized, the support from the local authorities is greater. The value of the inclusion of Ukrainians to the social and political life of the Warmian-Masurian Voivodeship has been proven. It is about the situation when active representatives of the Ukrainian community run to the Voivodeship's representative bodies at various levels. It have been emphasized on a number of problems faced by the Ukrainian community in Warmian-Masurian Voivodeship, which are common to the Ukrainian diaspora in Poland, namely: structural separation of the organization of Ukrainians, lack of activists, insufficiency of the financial system at the self-government level, outflow of youth, problems of communication, etc.

Key words: national minority, Ukraine, Poland, Warmian-Masurian Voivodeship. 


\title{
ПРІОРИТЕТНІ НАПРЯМИ ДІЯЛЬНОСТІ УКРАЇНСЬКОЇ МЕНШИНИ У ВАРМІНСЬКО-МАЗУРСЬКОМУ ВОСВОДСТВІ РЕСПУБЛІКИ ПОЛЬЩА
}

\author{
Леся Дорош \\ Національний університет “Львівська політехніка" \\ lesia.o.dorosh@lpnu.ua \\ Researcher ID R-1453-2017 \\ Author ID: 57192267003 \\ Ярина Турчин \\ Національний університет “Львівська політехніка" \\ turchynj@ukr.net \\ Researcher ID R-1932-2017 \\ Author ID: 57192268948 \\ Тереза Астрамович-Лейк \\ Вармінсько-Мазурський Університет в Ольштині \\ teresa.astramowicz@uwm.edu.pl \\ ORCID 0000-0001-5881-2325
}

\begin{abstract}
Проаналізовано особливості, виклики та пріоритетні напрями функціонування української громади у Вармінсько-Мазурському воєводстві, а також досліджено генезу діяльності української національної меншини у цьому регіоні 3 повоснних часів $\mathbf{i}$ до сьогодні. Стверджується про затребуваність вивчення проблематики функціонування української національної меншини у Польщі у регіональному вимірі, коли аналізується діяльність українських громад в різних восводствах. Таке дослідження актуалізусться 3 погляду виявлення факторів, що визначають розвиток усесторонньої співпраці України і Польщі. Проаналізовано діяльність трьох осередків Об'сднання українців у Польщі у цьому регіоні. Враховано зусилля місцевої влади у підтримці культурних проектів української національної меншини, наданні фінансової й організаційної підтримки в їх діяльності. Підтверджено закономірність - там, де українців с достатньо і вони добре організовані, то більшою с підтримка 3 боку місцевої влади. Доведено значення долучення українців до суспільно-політичного життя ВармінськоМазурського воєводства, коли активні представники української громади балотуються до представницьких органів влади воєводства різного рівня.
\end{abstract}

Ключові слова: національна меншина, Україна, Польща, Вармінсько-Мазурське воєводство.

Poland and Ukraine, both in territorial terms and in terms of population, are two of the largest states in Central and Eastern Europe. After the collapse of the Soviet Union, these countries have started their own path of state and social transformation. They have implemented important reforms and met with considerable challenges and obstacles on their path. At the end of the twentieth century, there were several significant events that have created the preconditions for the cultural revival of the Ukrainian community on the territory of Poland. First of all, it is the restoration of state independence of Ukraine, the democratization of the structural elements of its political system, and the European integration choice of the Ukrainian people [Турчин 2014]. Nowadays, both of these countries are mutually interested in the development of comprehensive cooperation due to several factors. According to Andrzej Sheptytsky, these factors are as follows: direct neighborhood, common (but difficult) history, attractiveness of the Polish labor market for Ukrainians, Poland's membership in Western integration structures, and the threat and aggression of the Russian Federation (which is well understood by the two sides) [Szeptycki 2016]. The development of strategic partnership between the two countries depends not only on the efforts of the political elites of the countries but also on direct communication at the level of civil society. Thus, ethnic minorities living in both countries have a significant potential for the development of good-neighbourly relations.

Of all countries of the European Union, the largest autochthonous Ukrainian community was formed in Poland, which is primarily explained by the change of borders in the past [Свтух 2005]. Mostly, the Ukrainian minority is compactly located in the northern and western regions of the country. The largest number of ethnic Ukrainians (more than 12.000 people) live in the Warmian-Mazur Voivodship (Olsztyn), while in the Lower Silesian Voivodeship (Wroclaw) lives over 3.500 people. Also, in the West Pomeranian (Szczecin) Voivodeship the population reaches almost 3.000 Ukrainians. In Subcarpathian Voivodeship (Rzeszow) there are more than 2.500 Ukrainians. In Pomeranian Voivodeship (Gdansk) there are approximately 2.000 Ukrainians. Finally, in Lesser Poland Voivodeship (Krakow) population reaches almost 2.000, and in Podlaskie Voivodeship (Bialystok) there are approximately 1.500 Ukrainians. So, according to official 
statistics, there are more than 40.000 Ukrainians, and unofficially there are more than 200.000 Ukrainians in Poland. As we see, there is a tendency for a significant reduction of the autochthonous Ukrainian population in Poland, when a significant part of the Ukrainian community has already completely assimilated. It is the warning fact that the generation of those Ukrainians who were born on the territory of Poland gradually lose their connection with the ethnic homeland, assimilate with the Polish society and do not identify themselves as Ukrainians [Турчин 2014].

Olsztyn is the administrative centre of the Warmian-Masur Voivodship. Warmian-Masur Voivodship is one of the most ethnically diverse regions of modern Poland. There are such national and ethnic minorities there: Ukrainians (11.881 people according to the 2002 census), Germans (4.311 people according to the 2002 census), Mazury (about 15.000), Varmians (about 4.000), Belarusians (5.000-3.000), Roma (1.000), Lithuanians (300-400), Tatars, Russians, and others. The largest number of ethnic Ukrainians lives in the WarmianMasurian Voivodship, who has had a significant influence on the development of the region. By the way, Bani Mazurski, because of the large presence of Ukrainians in the 70-80s of the 20th century, was called "the capital of the Masurian Ukraine" [CzetyrbaPiszczako, Czetyrba 2015].

The purpose of this article is to investigate the features, challenges, and priorities of the functioning of the Ukrainian community in the Warmian-Masurian Voivodeship as well as to demonstrate the genesis of the activities of the Ukrainian national minority in this region since the post-war times to this day.

The source base of research includes the works analyzing the relations between Ukraine and Poland in general and in the national and ethnic spheres in particular [Турчин 2014; Свтух 2005; Podrucka, Szkoła 2011]. It should be mentioned the studies that emphasize the problems and challenges (in historical and contemporary dimensions) of bilateral relations [Szeptycki 2016]. The information from official sources of state structures and diplomatic missions of Ukraine in Poland, representations of the Ukrainian community in this country, as well as official data of Polish authorities have become the basis of the proposed study [Посольство України у Республіці Польща 2019; Консульство України у Гданську 2019; Сподарик 2016; Мігус 2018; Лопата 2017]. It also was used the information materials about the political and public representation of Ukrainians in local and regional authorities and local self-government [Лоза 2018a, 2018b, 2018c; На місцевих виборах 2018]. А significant amount of information was used from the main printed and electronic publication of Ukrainians in Poland - "Nashe Slovo" ("Our word") [Сподарик
2016; Мігус 2018; Лопата 2017; Лоза 2018a, 2018b, 2018c]. State of the study of the problems of functioning of the Ukrainian national minority in Poland indicates a significant interest of scientists to the issues. At the same time, it is in demand to study this issue in a regional dimension when analyzing the activities of Ukrainian communities located in certain Voivodeships (in this case, the Warmian-Masurian).

A significant number of Ukrainians (about 56.000 people) live in the Voivodship (former lands of East Prussia) as a result of "Operation Vistula", which was carried out by a communist regime in 1947. Deported Ukrainians came here from their native land, located in the neighbourhood of Przemysl, Syanok, as well as from the Beskydy. Today, the Ukrainian minority is one of the most influential national communities in this multicultural region. The activities of the Ukrainian national minority in the Warmian-Masurian Voivodeship are regulated by a number of normative documents. The main ones are the Constitution of the Republic of Poland and the Law of the Republic of Poland "On National and Ethnic Minorities and on the Regional Language". Narrowing the focus of attention to the WarmianMasurian Voivodeship, the Ukrainian community receives special support from local authorities, mainly thanks to the work of the Commission on National and Ethnic Minorities, which was established at the Warmian-Masurian Sejmik in 1999 and has been headed for many years by Authorized of Marshal of the Warmian-Masurian Voivodship for National Minorities Victor Marek Leik. The chairman of the Commission emphasises that Ukrainians are ostentatious power, they are well-organized, full of initiatives, working people. It is the largest minority in the region, and perhaps even in Poland. It is believed that about 80.000 of Ukrainians live in Warmia and Mazury [Мігус 2018]. Cultural projects of the Ukrainian national minority are supported by the local authorities, financial and organizational support is provided. Actually, the Warmian-Masurian Voivodeship confirms the thesis of the well-known researcher of the Ukrainian diaspora in Poland, Bogdan Galchak, that such a pattern is being observed: where Ukrainians are sufficient and well organized, the support of the local authorities is greater [Halczak 2012].

The activity of Ukrainians is concentrated around the departments of the Union of Ukrainians in Poland (UUP). There are three departments of the UUP in this region: 1) Mazury (headed by Kateryna Polevchak); 2) Elblong (headed by Stepan Dembitsky); and 3) Olsztyn (headed by Stepan Migus). For example, the active members of the Olsztyn department are Petro Tabaka (a teacher at the Ukrainian language training school), who is dealing with organizational issues of the branch, Stefania Lykosh (member of the Main Board of the UUP), Mykhailo Kayda (head of the Olsztyn section), 
Andrii Sydor (head of the section in Kentshina), Mykhailo Zubalsky (head of the section in Bobre Mjasto), Grigory Stepanyuk (secretary of the UUP section in Bartoshets), Lubomyr Zholodok (head of the section in Ilawa), Boguslav Tabaka (head of the section in Srokov) [Сподарик 2016].

Basically, Ukrainians in Poland are associated with achievements in culture, art and folklore. The representatives of the Ukrainian community who live in the Warmian-Masurian Voivodeship and are actively involved in the strengthening of the multiculturalism of this region are also emphasizing their presence through the activities in the field of culture.

This type of activity is directly related to the ability of Ukrainians to learn with their native language. The basis of Ukrainian minority development, support and promotion of Ukrainian cultural heritage in the region, is formed by the network of Ukrainian schools (two complexes) and places of the study of Ukrainian Language (51 places). At the national level, the availability of Ukrainian language education in Polish schools is guaranteed by a number of legal acts, including the special order of the Ministry of Public Education (2007), which guarantees the support and development of the sense of national identity of children of national minorities, as well as the commitment of educational institutions to organize lessons of studying of native language where people are willing. The Government of Poland grants local governments with special grants for children from national minorities for the teaching of their native language. If the state provides 5.000 PLN per year to study an average Polish student, 7.000 PLN are provided to one Ukrainian child per year from the state budget. Consequently, it encourages local authorities to establish such centres for the study of the language of national minorities [Савицький 2013].

In the Warmian-Masurian Voivodship, there are about 700 children studying Ukrainian language. For example, 120 children are studying in the Ukrainian school of Lesia Ukrainka in the town of Bartoszyci (director Lyuba Thir). A powerful Ukrainian school is also in Gurov-Ilovetskiy (headed by Maria-Olga Sych), where 300 students attend. There are also more than 50 places of the study of Ukrainian Language. There are various artistic groups, ensembles and choirs in the schools of the Voivodeship. Also, there are continuous events devoted to the prominent dates of Ukrainian history.

In general, it should be noted the high level of national consciousness of the younger generation of Mazurian Ukrainians. At the same time, according to Stepan Migus, there is a lack of direct "communication" with the ethnic homeland in the form of several weeks of Ukrainian-language schools for pupils, which were supported by Ukraine previous years. This practice was quite effective, but due to financial difficulties there no more of such practices in this field [Мігус 2018].

Today, Olsztyn is a regional centre that attracts more and more of young Ukrainians, especially university students. The Faculty of Ukrainian Philology at the University of Warmia and Mazury is successfully functioning. It should be noted about the active cooperation of the University of Warmia and Mazury with higher educational institutions of Ukraine, mainly with the Lviv Polytechnic National University, Ivan Franko Lviv National University. University professors actively cooperate in the field of science, conduct joint research, implement various international projects, common and double degree diploma programs, and actively organize and conduct international scientific and practical conferences. There is intensively developed cooperation between the University of Warmia and Mazury and Lviv Polytechnic National University, officially launched in 2015 (the coordinators of cooperation are Professor Teresa Astramovich-Leik and Professor Yaruna Turchyn). Since 2015 the UkrainianPolish scientific forums, which bring together scientists, politicians, youth, and civil society representatives around the issues of cooperation between Ukraine and Poland, are being held every year by the efforts of both institutions with the support of the Warmian-Masurian Sejm.

The activity of Ukrainians in the information space is also very important, which greatly has intensified with the introduction of the new media technologies. There is widespread newspaper "Nashe Slovo" of the Ukrainian community in Poland in the Voivodship. Ukrainian Igor Hryvna is the editor-in-chief of the newspapers "Gazeta Olsztynska" and the website ukraincy.wm.pl is functioning on the Internet. There is the editorial office of the magazine "Blahovis't", as well as the city site gorowo.pl. in Gurovo-Ilavetskij. On the waves of "Radio Olsztyn" sound radio broadcast programs in Ukrainian every day and Ukrainian TV shows are broadcasting on the regional television. In addition, the magazine "Ridna mova" ("Native language") is widespread (the editor is the well-known Ukrainian teather in Poland Marco Syrnyk).

The region often hosts the days of Ukrainian theater, the festivals of European nations "Under the open sky", "The colors of Ukrainian culture", "E-Colomyja", "The Night of Ivan Kupala", Days of Ukrainian culture, Regional Ukrainian fair "From drawing box", International Church Music Days, Ukrainian Theater Days, International Festival of Children's Folklore Groups of National Minorities, various master classes, Shevchenko concerts, etc. The Ukrainian-Polish television and radio festival "Kalynovi mosty", which is organized by the Olsztyn branch of the Union of Ukrainians in Poland, Radio Olsztyn and the 
Rivne State TV and Radio Company, has been held several times in the Voivodeship [Одарченко 2014]. There are numerous dance and song bands, such as "Dumka" ("Idea"), "lisova pisniia" ("Forest song"), "Dar Liubovi" ("Gift of love"), etc. We see that today cultural events of Ukrainians are often taking place in the region; they have their own history and supporters. However, according to representatives of the Ukrainian community, the attendance of such events could be better. Therefore, it is necessary to search and add other forms of informing the audience about Ukraine, not only of entertainment manner.

An extremely important factor for the development of the Ukrainian community in Poland is the normalization of the situation with the Greek Catholic Church, which in 1989 received its bishop Jan Martyniak. Actually, from this moment has come an era of its dynamic development. Today in Poland there are 120 Greek Catholic parishes, which are serviced by 80 priests and have 200,000 parishioners [Halczak Bohdan 2012]. It is important that the two largest Greek-Catholic parishes, Asun and Kentshina, which belong to the Wangozhian Deanery, are operating in the WarmianMasurian Voivodship. However, the number of parishioners is decreasing, especially among the younger generation of Ukrainians.

One of the most important challenges is finding a balance between traditional cultural activities and other forms of activity. Therefore, a special sphere of activity of the Ukrainian community is gaining a significance today - the inclusion in the social and political life of the Warmian-Masurian Voivodeship. Active representatives of the Ukrainian community often run to the representative bodies of the Voivodship of different levels. For example, the head of the Warmian-Masurian Sejm during the three convocations was Ukrainian Myron Sych. This politician also was twice a deputy to the Polish Sejm, headed the parliamentary Commission of National and Ethnic Minorities, and today he is a Vice Marshal of the Warmian-Masurian Voivodship.

However, it should be noted that, unfortunately, since 2014, there were no individuals who are members of the Ukrainian minority and are active and organize or support Ukrainian initiatives at the Sejm level. At the same time, according to Stepan Migus, some heads of districts, bourgeois masters, and 40 deputies of different levels in the Voivodship were Ukrainians. Undoubtedly, this has become a significant achievement for the Ukrainian community in the Voivodship [Мігус 2018].

On October 21, 2018, elections were held in Poland to the self-government bodies of Gmins, districts, Sejms of Voivodships, as well as the mayors of cities. In total, there were 95 candidates representing the Ukrainian community. 39 of them have won [Лоза 2018b]. According to the results of the vote, among the deputies of the Sejm of the Warmian-Masurian Voivodeship, there will be two Ukrainians: Myron Sych (won 11835 votes) and Zbyshko Gomza (doctor, deputy chairman of the district council in the city of Kentshin) (won 7915 votes). These two candidates are representatives of the Ukrainian community and headed the electoral list of the "Civil coalition", which is created by the parties "Civil Platform" and "Novochesna". In general, more than 15 representatives of the Ukrainian community will work in the representative bodies of the Voivodeship of different levels. During the elections, in the second round on November 4, 2018, Slavomyr Kovalchyk, one of the candidates for the gmina Svjontka, won $51,71 \%$ of the votes [Лоза 2018c].

However, the level of political representation of a large Ukrainian community is not sufficient. This can be explained by the generally low level of political activity of Polish Ukrainians, which is justified by several reasons: the dispersal nature of Ukrainians living on the territory of the Republic of Poland, the confession of the Polish Ukrainians, the established negative stereotype of Ukrainians, which is still fixed in the minds of the Poles, and too weak support of the Ukrainian diaspora by the "Mother" state [Турчин 2014].

The Ukrainian community in the WarmianMasurian Voivodeship has faced a number of problems in its functioning, which are generally characteristic to the Ukrainian diaspora in Poland. According to the leaders of the Ukrainian national minority, the structural strengthening of the organization of Ukrainians is a key issue for the present. It is about staffing issues, which are a real challenge for an organization, because of a lack of willingness to engage in such activities. It is also noted not only lack of activists, but also the lack of financial support at the level of self-government, the outflow of youth, the complexity of the combination of public and professional activities. Also, this list includes problems of communication content that reduce the productivity of the Ukrainian community. To solve these problems it is necessary to develop existing ones and create new centres, to develop a website at the regional level, etc., which will allow better public work and earning money for their own needs [Мігус 2018].

In addition, it should be noted about the threat posed by internal divisions in the Ukrainian community. For example, the former members of the Union created their own structure in the Kentshynschyna. Therefore, the urgent need is the consolidation of Ukrainian initiatives in the region, the search for the momentums that will unite, and not divide the Ukrainian community. It should be noted that the problem of fragmentation is general 
characteristic of the Ukrainian community of Poland [Halczak 2012].

Summarizing the analysis of the current state and prospects of Ukrainian minority activity in the WarmianMasurian Voivodeship, it should be noted about the multiculturalism and multi-ethnicity of the region. So, it should be stressed on the need for more and more communication of representatives of the Ukrainian community with representatives of other national communities for coordination of joint activities for the protection and support of national minorities in the region. In this way, through communication with the Motherland, Polish authorities and citizenship, other national communities will have the opportunity to express as much as possible the urgent problems of the national development of the country, identify and communicate to the public the key threats to interethnic communication, and, thus, improve the overall quality of life and diversify the forms of activity of the Ukrainian community in Poland in order to protect national identity, culture and language.

\section{ЛІТЕРАТУРА}

Голодрига, Ю. (2018). У цьому воєводстві чи не найбільша громада українців - хто вони, як живуть і чому опинились у Польщі (2018), Eксnрес, 25 січня. Отримано 3 https://expres.online/archive/digest/2018/01/25/281727-comuvoyevodstvi-ne-naybilsha-gromada-ukrayinciv-hto-vonyzhyvut-chomu

Євтух, В., Трощинський, В., Попок, А. (2005). Закордонне українство. Навчальний посібник. Київ: ВІК.

Консульство України у Гданську. (2019). Отримано 3 https://gdansk.mfa.gov.ua/ua

Лоза, П. (2018а), Українські кандидати у виборах до сеймику Вармінсько-Мазурського воєводства. Наше слово, 11 липня. Отримано 3 http://www.nasze-slowo.pl/news/ ukrainski-kandidati-u-viborah-do-sejmiku-varminskomazurskogo-voievodstva/

Лоза, П. (2018b). 38 українців перемогли у місцевих виборах у Польщі. Наме слово, 25 жовтня. Отримано 3 http://www.nasze-slowo.pl/news/32-ukrainci-peremogli/

Лоза, П. (2018c). Українці та другий тур місцевих виборів у Польщі. Наше слово, 6 листопада. Отримано 3 http://www.nasze-slowo.pl/news/ukrainci-ta-drugij-turmiscevih-viboriv-u-polshhi/

Лопата, О. (2017). Яким є потенціал української громади у Польщі? Наше слово, 1 жовтня. Отримано 3 http://www.nasze-slowo.pl/jakim-ie-potencial-ukrainskoigromadi-u-polshhi/

Мігус, С. (2018). Форум активності задля майбутнього, Наше слово, 15 жовтня. Отримано 3 http://www.nasze-slowo.pl/forum-aktivnosti-zadljamajbutnogo/

На місцевих виборах у Польщі здобули перемогу 38 українців. (2018). ZIK, 31 жовтня. Отримано 3 https://zik.ua/news/2018/10/31/na__ mistsevyh _vyborah _u_polshchi_zdobuly_peremogu_38_ukraintsiv_1437939
Одарченко, В. (2010). 63-ті роковини акції "Вісла". Paдio Свобода, 28 квітня. Отримано 3 https://www. radiosvoboda.org/a/2027313.html

Одарченко, В. (2014). “Калинові мости” до Європи через фестиваль журналістів Польщі та України. Padio Свобода, 30 червня. Отримано 3 https://www. radiosvoboda.org/a/25439616.html

Посольство України у Республіці Польща. (2019). Отримано $з$ https://poland.mfa.gov.ua/ua

Савицький, Ю. (2013). Щоб вивчати українську мову в польській школі, достатньо заяви трьох батьків. Paдio Свобода, 16 травня. Отримано 3 https://www. radiosvoboda.org/a/24987373.html

Сподарик, Г. (2016). Рада Ольштинського відділу ОУП. Наше слово, 24 квітня. Отримано 3 http://www.naszeslowo.pl/rada-olshtinskogo-viddilu-oup/

Турчин, Я. (2014), Українська держава та закордонне українство в Польщі: особливості взаємодії. Украӥнська національна ідея: реалії та перспективи розвитку, № 26, 149-155.

Czetyrba-Piszczako, M., Czetyrba, M. (2015). Tożsamość kulturowa i identyfikacja językowa Ukraińców Warmii i Mazur. Studia Wschodniostowiańskie, Tom 15. Отримано 3 https://pbn.nauka.gov.pl/sedno-webapp/getFile/21188

Halczak, B. (2012). Ukraincy (po 1989 r.). In S. Dudry, B. Nitschke (eds.), Mniejszości narodowe i etniczne w Polsce po II wojnie światowej, 113-127. Kraków: Nomos.

Podrucka, P., Szkoła, J. (2011). Ukraińcy jako diaspora i mniejszość narodowa w Polsce - ujęcie retrospektywne i współczesne. Zeszyty naukowe ruchu studenckiego, $\mathrm{Nr}$ 1, 88102. Отримано $3 \mathrm{http}: / /$ rsawl.awl.edu.pl/images/Archiwum/ 2011/nr_1/podrucka_p_szkola_j.pdf

Szeptycki, A. (2016). Poland-Ukraine Relations. Revista UNISCI/UNISCI Journal, No.40 (Enero / January 2016).

\section{REFERENCES}

At the local elections in Poland 38 Ukrainians have won. (2018). [In Ukrainian]. ZIK, $31^{\text {st }}$ October. Retrieved from https://zik.ua/news/2018/10/31/na_mistsevyh_vyborah_u_polsh chi_zdobuly_peremogu_38_ukraintsiv_1437939

Consulate of Ukraine in Gdansk. (2019). [In Ukrainian]. Retrieved from https://gdansk.mfa.gov.ua/ua

Embassy of Ukraine in the Republic of Poland. (2019). [In Ukrainian]. Retrieved from https://poland.mfa.gov.ua/ua

Halczak, B. (2012). Ukraincy (po 1989 r.). In S. Dudry, B. Nitschke (eds.), Mniejszości narodowe i etniczne w Polsce po II wojnie światowej, 113-127. Kraków: Nomos.

Holodryha, Yu. (2018). In This Voivodship is Perhaps the Largest Community of Ukrainians - Who They Are, How They Live and Why They Find Themselves in Poland. [In Ukrainian]. Express, 25 $5^{\text {th }}$ January. Retrieved from https://expres.online/archive/digest/2018/01/25/281727-comuvoyevodstvi-ne-naybilsha-gromada-ukrayinciv-hto-vonyzhyvut-chomu

Lopata, O. (2017). What is the potential of the Ukrainian community in Poland? [In Ukrainian]. Our Word, $1^{\text {st }}$ October. Retrieved from http://www.nasze-slowo.pl/jakim-iepotencial-ukrainskoi-gromadi-u-polshhi/

Loza, P. (2018a). Ukrainian candidates in elections to the Sejm of Warmian-Mazur Voivodship. [In Ukrainian]. Our Word, $11^{\text {th }}$ July. Retrieved from http://www.nasze- 
slowo.pl/news/ukrainski-kandidati-u-viborah-do-sejmikuvarminsko-mazurskogo-voievodstva/

Loza, P. (2018b). 38 Ukrainians won the local elections in Poland. [In Ukrainian]. Our Word, $25^{\text {th }}$ October. Retrieved from http://www.nasze-slowo.pl/news/32-ukrainci-peremogli/

Loza, P. (2018c). Ukrainians and the second round of local elections in Poland. [In Ukrainian]. Our Word, November, 6. Retrieved from http://www.nasze-slowo.pl/news/ukrainci-tadrugij-tur-miscevih-viboriv-u-polshhi/

Migus, S. (2018). Activity Forum for the Future. [In Ukrainian]. Our Word, 15 ${ }^{\text {th }}$ October, 15. Retrieved from http://www.nasze-slowo.pl/forum-aktivnosti-zadljamajbutnogo/

Czetyrba-Piszczako, M., Czetyrba, M. (2015). Tożsamość kulturowa i identyfikacja językowa Ukraińców Warmii i Mazur. Studia Wschodniostowiańskie, Tom 15. Retrieved from https://pbn.nauka.gov.pl/sedno-webapp/ getFile/21188

Odarchenko, V. (2010). 63th anniversary of the action "Vistula". [In Ukrainian]. Radio Liberty, April, 28. Retrieved from https://www.radiosvoboda.org/a/2027313.html

Odarchenko, V. (2014). "Kalyna Bridges" to Europe through the festival of journalists from Poland and Ukraine. [In
Ukrainian]. Radio Liberty, June, 30. Retrieved from https://www.radiosvoboda.org/a/25439616.html

Podrucka, P., Szkoła, J. (2011). Ukraińcy jako diaspora i mniejszość narodowa w Polsce - ujęcie retrospektywne i współczesne. Zeszyty naukowe ruchu studenckiego, $\mathrm{Nr}$ l, 88-102. Retrieved from http://rsawl.awl.edu.pl/images/ Archiwum/2011/nr_1/podrucka_p_szkola_j.pdf

Savitsky, Yu. (2013). To study Ukrainian in the Polish school, there are enough statement from three parents. [In Ukrainian]. Radio Liberty, May, 16. Retrieved from https://www.radiosvoboda.org/a/24987373.html

Spadaryk, H. (2016). Council of the Olsztyn Department of UUP. [In Ukrainian]. Our Word, $24^{\text {th }}$ April. Retrieved from http://www.nasze-slowo.pl/rada-olshtinskogoviddilu-oup/

Szeptycki, A. (2016). Poland-Ukraine relations, Revista UNISCI / UNISCI Journal, No.40 (Enero / January 2016)

Turchyn, Y. (2014). Ukrainian state and foreign Ukrainians in Poland: features of interaction. [In Ukrainian]. Ukrainian national idea: realities and prospects of development, No. 26, 149-155.

Yevtukh, V., Troshchinsky, V., Popok, A. (2005). Foreign Ukrainians. Textbook. [In Ukrainian]. Kiyv: VIK. 